\title{
Sperm Protein Associated With the Nucleus on the X Chromosome A
}

National Cancer Institute

\section{Source}

National Cancer Institute. Sperm Protein Associated With the Nucleus on the X

Chromosome A. NCl Thesaurus. Code C92977.

Sperm protein associated with the nucleus on the $\mathrm{X}$ chromosome $\mathrm{A}(97 \mathrm{aa}, \sim 11 \mathrm{kDa}$ ) is encoded by the human SPANXA2 and SPANXA1 genes. This protein plays a role in spermatogenesis. 